\title{
Giovanni Capellini and the origin of the International Geological Congress
}

Department of Earth and Geological-Environmental Sciences, University of Bologna, Via Zamboni 67, I-40127 Bologna, Italy. E-mail: vai@geomin.unibo.it

The International Geological Congress (IGC), originally the International Congress of Geologists, was founded on August 25, 1876, at the 25th Meeting of the American Association for the Advancement of Science, held in Buffalo, New York. The founding committee was composed of participants from the USA and Canada, with the addition of two geologists from Sweden and The Netherlands. Why did it take so many years after its establishment for the countries represented in the founding committee to host the IGC, beginning with the 5th IGC, held in Washington D.C. in 1893? The answer may be in documents, which point to the idea of the IGC originating from Giovanni Capellini as a result of his journeys in Europe and North America, especially through discussions with his French and Swiss friends. Capellini was the first titular chair of geology funded by the new-born Italian state in Bologna. European travels reinforced Capellini's intention to create a great geological museum designed to store types and standards of fossils, rocks, lithic tools, and materials used for geological mapping, mining exploration, land planning, and improving agriculture. His long geological travel through North America in 1863 allowed Capellini to convey to many North American geologists his conviction that there was need for an international forum to reach a wide agreement on stratigraphy, palaeontology and mapping. During his 1863 trip, Capellini became a friend of three future members of the IGC founding committee and familiar with two others through common acquaintances. Perhaps, the Italian-French group of leading figures who first conceived of the IGC asked their North American colleagues to make a proposal from abroad. This same successful procedure of an 'outside' request was followed in founding the International Congress of Anthropology and pre-Historical Archaeology in 1865. The idea came from French scientists who confidentially asked Capellini to found the congress and suggested to hold the first session in Neuchatel in 1866 and the second in Paris in 1867. This then may be the key to understanding why the first four IGCs were held in France, Italy, Germany, and UK before one took place in the USA where the IGC was founded.

\section{Introduction}

The General Proceedings of the International Geological Congress (IGC) held in China in 1996 (Anonymous, 1997, partly consistent with Hanshaw, 1990) record that the IGC was officially founded at the 1876 Centennial Exhibition in Philadelphia, by ratification of the suggestion of a founding committee which had deliberated the need for such an assembly at the meeting of the American Association for the Advancements of Science (AAAS) in Buffalo, N.Y., in 1875. The positive decision was taken because, "fundamental differences in exhibited geological maps of North America and Europe were observed. Thus the need to codify common geological map symbols, nomenclature and colours became apparent. And what better way to accomplish this than by holding international meetings on the subject every several years!" (Hanshaw, 1990). The founding committee was composed of the following geologists: President: James Hall (USA), Secretary: Thomas Sterry Hunt (Canada), Members: William B. Rogers (USA), J. William Dawson (Canada), John S. Newsberry (USA), Charles H. Hitchcock (USA), Raphael Pumpelly (USA), J. Peter Lesley (USA), Thomas H. Huxley (UK), Otto Torell (Sweden), E.H. von Baumhauer (The Nederlands).

Given the composition, it is surprising that none of the countries represented on the founding committee was to host an IGC before the 4th session (UK), the 5th (USA), the 11th (Sweden), and the 12th (Canada). Why did France, Italy, and Germany come first? Was it due to a fair attitude of the founding Committee or were there other reasons? The answer to this mystery may lie in the autobiography of Giovanni Capellini (1914) and official documents of the earliest IGCs.

Moreover, the origin of the IGC seems to have been quite different from that reported above. One error in Hanshaw and other authors concerns the AAAS. No meeting of the AAAS was held in Buffalo in 1875 (see below). The aim of this paper, therefore, is to unravel the hidden story and the key persons who succeeded in establishing this important global organization, that remains alive and vibrant after more than 120 years.

\section{Giovanni Capellini and the first chair of geology in Italy (1860)}

The story of the origin of the IGC dates to the mid-19th century. In 1860, a young 28 year-old Italian scientist, Giovanni Capellini (1833-1922) (Figure 1), was granted the first Italian chair of geology in the University of Bologna. The chair was established by the newly-founded Italian national state. Capellini was a brilliant selfmade man who graduated from the University of Pisa, where Paolo Savi and Giuseppe Meneghini, among the leading Italian geologists and palaeontologists, worked at that time. For example, one of the first true geological maps of Italy was published in Pisa by Savi in 1832. The Pisa and Tuscan school of geology by tradition had been preserved by the diluvianistic theories, so from the beginning the young Capellini was an enthusiastic supporter of Darwin's ideas on 


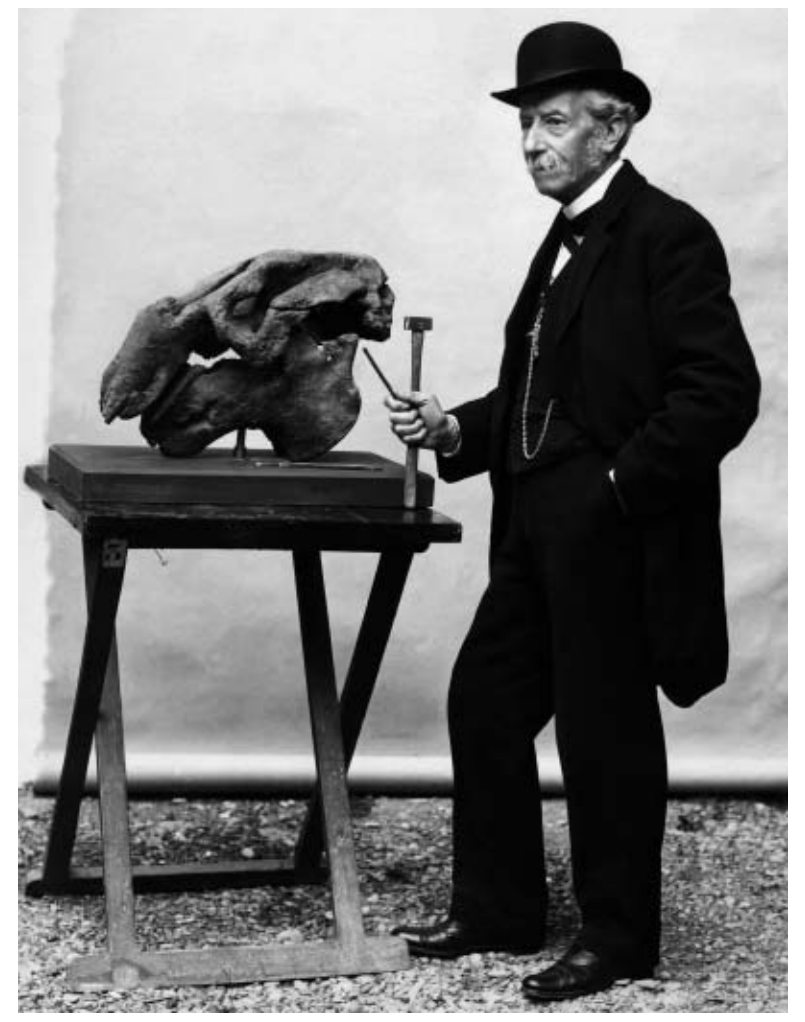

Figure 1 Official portrait of Capellini at work in the museum.

evolution. Sending an open-minded young professor of geology to the old and famous University of Bologna, renowned also for its persistent diluvianistic attitude, was a sign that the newly formed Italian state, keen to take a positivistic approach, was trying to re-orient education and culture in the second largest city of the former Church states. Capellini's high skill in geological mapping was taken by the Ministry of Education as assurance that the new elite, emerging from the university, would contribute to expanding the benefits that a search for new resources and more refined geological knowledge of the country would bring to progress of the new state and of Italian society as a whole.

Capellini was born into a low-middle class family. He compensated for lack of financial means by his intellectual talent, obtaining support from authorities and potentates to the level of European royal families. He was the first among the great geologists of the Bologna school (Aldrovandi, Cospi, Marsili, Monti, etc.) to lack a noble origin. In spite of his progressive scientific views, Capellini was an openly conservative person, respectful of the scientific and cultural views of others, including his diluvianistic predecessors in Bologna and their glorious heritage.

\section{The European travels of Capellini}

When entering the University of Pisa as a student, Capellini was already elected a corresponding member of the Halle Society of Naturalists. From the beginning, therefore, his teaching and research activity, although rooted in his country, was planned and played out in the European arena. In the early years (1858-60), he already enjoyed strong and wide-ranging personal scientific relations with leading scientists, especially geologists, palaeontologists, and archaeologists, throughout Europe. For over three decades from 1858, Capellini was more often in Paris than in Rome or Florence. He spent most of the summers and other holiday periods in research and business meetings in France, Switzerland, Romania, Turkey, Great Britain, Belgium, Germany, Denmark, Sweden, Greece, and Hungary. After publication of D'Alambert's Encyclopédie, and as a consequence of the French revolution, and Napoleon's reforms, French replaced Latin as the international scientific language. Paris was the prime centre for culture, arts, and science. Both old prominent and young emerging geologists, especially those coming from southern European countries, could expect visibility and an international audience only through Paris and the Société Géologique de France.

As a mapping geologist, palaeontologist, and archaeologist, Capellini was fully aware that the academic progress and social benefit of the new geology were highly dependent on international stratigraphical and litho-technical correlation, through wide exchange of knowledge and experience, and on adequate standardization of language, techniques, and procedures in the new discipline and related professional curricula. Such principles were emphasized in the goals Capellini had set for his career, namely to build a new living geological museum in which one could study, compare, correlate, teach, and store the types and standards of fossils, rocks, and lithic tools, when combined with materials used for geological mapping, mining exploration, land planning, and soil evolution; this would improve modern agriculture, and foster discovery of new resources, including oil and gas. Capellini's boyhood dream was coming true. His favourite hobby as a boy - collecting curious natural objects and building apparatuses for physical experiments - was instrumental, when the young owner and his collection were presented to the Italian royal family, as one of the outstanding features worth of seeing during a visit, in 1853, to the town and resort area of La Spezia. Capellini, then only 19 years old, had the chance to get acquainted with and to become 'the oldest friend' of Umberto, the future King of Italy, and his brothers and sisters (Capellini, 1914).

When Capellini came to Bologna in 1860, he found there the more-or less-preserved remains of some of the world's first museums of natural history, those of Aldrovandi, Cospi, Marsili, Monti, and the new geological-archaeological museum of Giuseppe Scarabelli in the nearby city of Imola (Vai, 1995). His immediate decision was to restore to it's best the remains of the old Bologna museums and to compete with Scarabelli in building a large new museum for the new science and new society of the 19th century. He actually did so during his long life. However, to realize the titanic dream outlined above, good connections and exchanges were needed at an international, and even intercontinental, level.

\section{Capellini's voyage to North America (1863)}

Having already established close links with many European geological research institutions, Capellini decided to cross the Atlantic and visit the New World. The inspiration that he do so came from Charles Lyell, Philippe De Verneuil, and Roderick I. Murchison, and from Jules Marcou, a French friend who had moved temporarily to Cambridge, Massachusetts, some years earlier (Capellini, 1914). Marcou wrote to him (Capellini, 1914, v. 2, p. 78):

"Comme géologue ce voyage vous fera un bien énorme, en vous ouvrant des idées nouvelles, plus larges, plus vraies que celles que vous pouvez avoir avec votre connaissance d'une partie de l'Europe. L'avenir de la science réside dans les géologues voyageurs; c'est là ou il faut frapper pour faire des véritables progrès. ... Agassiz m'a dit de vous dire que il sera beaucoup hereux de vous voir" (March 31, 1863). [This trip will be extremely valuable to you as a geologist, opening your mind to new, wider and more reliable ideas as compared with those you may have obtained from your knowledge of a part of Europe. The future of science depends on travelling geologists; this is where to push for reaching true advancements. ... Agassiz told me to inform you he is very happy to meet you].

From this letter it appears also that Louis Agassiz — the most distinguished European naturalist who had moved to North America permanently — already knew Capellini. 


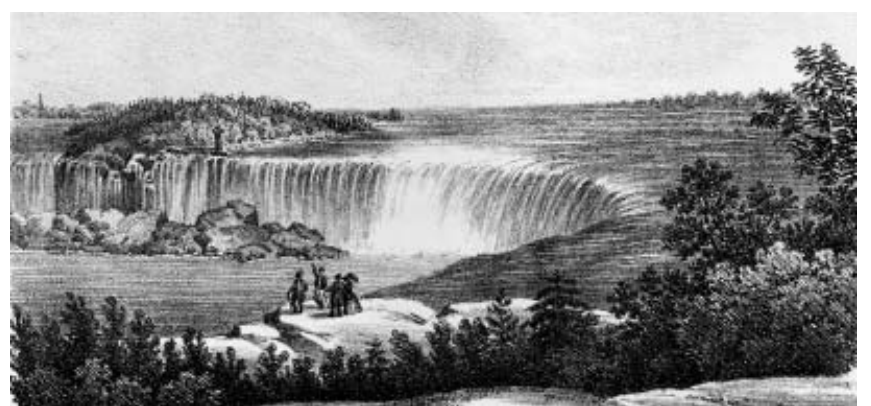

Figure 2 Niagara Falls, Ontario (from Capellini, 1867).

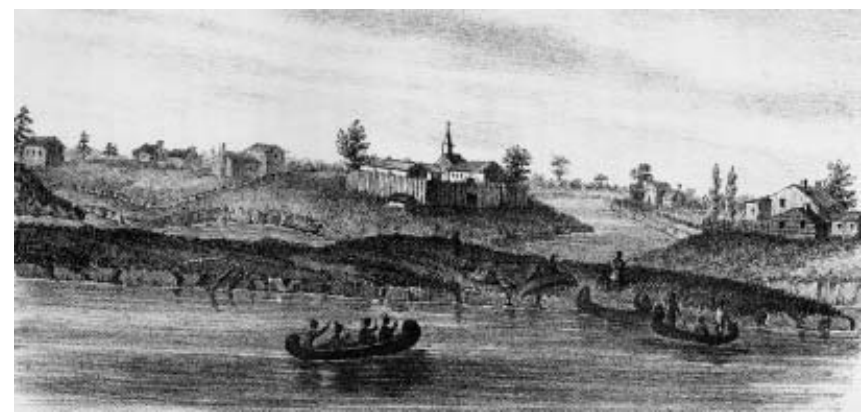

Figure 4 Chicago, Michigan in 1820 (from Capellini, 1867).

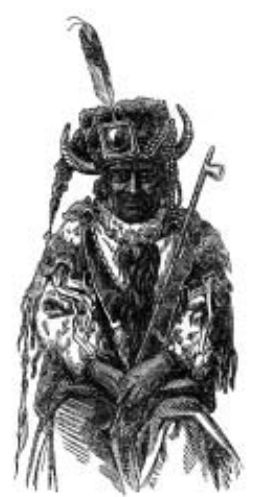

Figure 5 Ne-hi-ga-kuh, head of the Ponkas tribe, 65 years old in 1863 (from Capellini, 1867).

The 'brain drain' from Europe to North America had not yet started at that time; Agassiz and Marcou were prominent exceptions. It was even less common for European scientists to undertake research voyages outside the old world, such as those of Alexander von Humboldt, Darwin, Lyell, and De Verneuil, for example. Capellini was one of the few Europeans and the first Italian geologist therefore to seek for direct geological (and cultural) knowledge of North America (Capellini, 1864, 1867).

In Boston, Capellini met Agassiz who was anxious to show him his Aquarium and Museum of Comparative Zoology at the Harvard College. The nearly five month-long journey (Figures 2-6) took Capellini across Nova Scotia, Quebec, and Ontario, and across most of the eastern and central USA as far west as Nebraska, where he undertook first true geological exploration. He travelled tirelessly, collecting fossils, minerals, and rock samples, making stratigraphic correlations, looking at regional geology, visiting private collections and museums. Of special importance was his visit to the Smithsonian Institution in Washington, DC. He gave an admiring and detailed description of its history and content with special mention of the collections made by Owen, Jackson, Evans, Foster, Whitney, Warren, Henry and Baird. He met a few old colleagues and friends and made many new ones. All of this he accomplished despite the ongoing American civil war. Of special interest was his determination to come to know James Hall in Albany (New York State) and Edward Hitchcock in Amherst (Massachusetts) and to visit their collections. However, the search for keepers of palaeontological, geological, and natural history collections was so consistent throughout the journey that one can set down an additional list of scientists whom Capellini met and who were pleased to contribute parts of their collections to his future museum: Agassiz (Cambridge), Charles T. Jackson (Boston), William E. Logan, Elkanah Billings and Dawson (Montreal), Alexander Winchell (Ann Arbor),

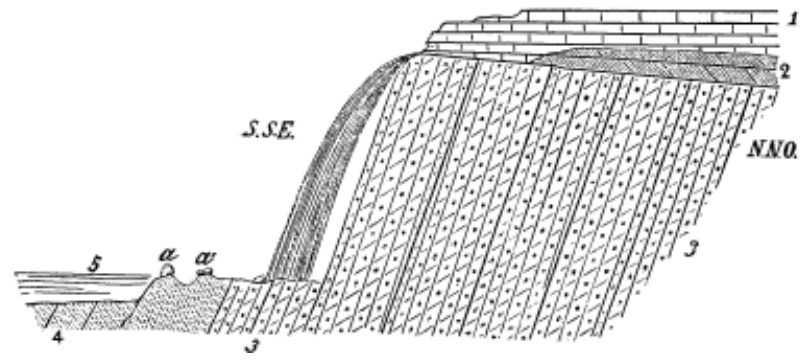

Figure 3 Geologic section across the Montmorenci Fall, Quebec (from Capellini, 1867). 1, Trenton Limestone; 2, Potsdam Sandstone?; 3, quarzite; 4, schists; 5, St. Lawrence River; aa', erratic boulders.

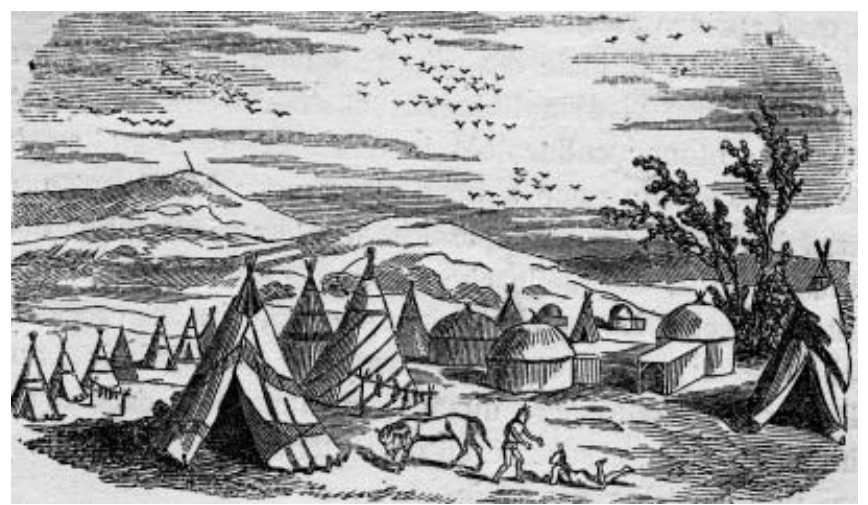

Figure 6 Big village and Ponkas tents in 1863 (from Capellini, 1867).

Charles A. White (Burlington), Charles Wachsmuth and Willis $\mathrm{H}$. Barris (Burlington), I.C.C. Hosckins (Sioux City), Holmes, Shumard and G. Engelman (St. Louis), Newberry (Louisville), Henry Christy (Cincinnati), Isaac Lea (Philadelphia), Charles U. Shepard (Amherst) (Capellini, 1867).

It is noteworthy that Hall, Newberry and Dawson became good friends of Capellini, and all were members of the founding committee of IGC reported above. Moreover, Edward Hitchcock insisted upon receiving Capellini and Marcou at his home, despite his lying in bed seriously ill. He showed Capellini some samples and offered him reprints of his papers. He died in 1864, a few months later and was the father of Charles H. Hitchcock, another member of the founding committee. Additionally, Newberry and White were close friends of Pumpelly, and Pumpelly of Dawson and Sterry Hunt (see Sarjeant, 1980). Rogers was President of the Massachusetts Institute of Technology from 1862 to 1870 , just at the time of Capellini's visit. Lesley was in close contact with P. Edouard Desor, one of Capellini's best friends. Therefore, three members of the later founding committee met and discussed international geological matters with Capellini during his North American journey, two additional ones probably met him who were, in turn, friends with three more. It is realistic to assume therefore, that already in those early years, to support his desire to obtain comparative samples for his museum, Capellini had spoken about the need for a single international forum to reach some worldwide agreement on aspects of stratigraphy, palaeontology, and mapping. This view certainly is suggested by Capellini's request when, armed with letters of introduction from Murchison and De Verneuil, he visited Logan, Director of the Geological Survey of Canada, in Montreal, and asked to be allowed to visit the collections that had been gathered as a basis for the Geological Map of Canada (Capellini, 1867). Capellini's friendship with Hall was so deep that Hall travelled to the 2nd IGC in Bologna, 1881, taking with him as a gift for the Capellini Museum a rich collection of Palaeozoic fossils from New York State. This collection remains one of the highlights of the Capellini Museum in Bologna. Agassiz was also very kind to Capellini during his trip, twice hosting 
him at his home, discussing with him the geology of Italy at length, and allowing him to mail collections to his home, which he then sent from Boston to New York without charging him.

\section{Foreign correspondents}

More than 30,000 of Capellini's letters are stored in the Archiginnasio Library of Bologna, an indication of how extensive were his public relations. Among his major foreign correspondents were: Agassiz, Charles Bernard, August Beyrich, Billings, G. Auguste Daubrée, H. Blanchard, Dawson, Albert Auguste De Lapparent, Gabriel De Mortillet, De Verneuil, Desor, Arnold Escher von Linth, Hugh Falconer, Oskar Fraas, J. Albert Gaudry, Jules A. Gosselet, Amanz Gressly, Hall, Edmond Hébert, Oswald Heer, John Herschel, Hitchcock, Edouard Lartet, Lea, Joseph Leidy, Logan, John Lubbock, Lyell, Alphonse Milne-Edwards, Johann Mojsisovics, Murchison, Sven Nilsson, Newberry, Albert Oppel, Shepard, Sterry Hunt, Torell, Carl Vogt, Christian von Meyer, White. Some of these, including Lyell (1857) and Falconer (1861), came to Italy to visit the young scientist and professor (together with the more mature G. Scarabelli), showing the high consideration he had received as early as 1857 in foreign countries (Capellini, 1914, v.1, pp. 135-140; v. 2, pp. 12.16).

Since his youth, Capellini had access to the entire Italian Royal Savoia Family, and through them he found easy connection to, and even won the friendship of kings, queens, and princes of many European countries (e.g. Christian IX of Denmark, Oskar II of Sweden, the queen mother Josephine of Sweden, Leopold of Belgium, and prince Napoleon, who visited him in Bologna in 1866).

Many of Capellini's friends and colleagues in Europe and North America, as well as in Italy, had relevant direct or indirect political influence in their respective countries, being members of parliaments or governments. This tool makes it easy to understand why many of his ideas, born as the dreams and aspirations of a young man, could became reality. His three main aspirations were: (1) to bridge the gap between his middle-class origin and the upper class, (2) to build a large museum, and (3) to set up rules tying the geological mapping to standard materials stored in museums, correlated and accepted worldwide. In the first two, he was lucky from the beginning. The third also succeeded, but took more time.

\section{The 2nd Congress of Naturalists in La Spezia 1865 and the foundation of the International Congress of Anthropology and pre-Historical Archaeology}

Capellini's first experience in organizing scientific conventions was made by at the 43rd session of the Sociéte Suisse des Sciences Naturelles (SSSN) at Lausanne in 1861. He became so skilled as to be able to lead international congresses from 1865 to 1907 (Capellini, 1914). Capellini was entrusted to chair and organize his first congress on behalf of the Italian Society of Natural Sciences when it held its 2nd session at La Spezia in 1865, following upon the 1 st, which was chaired by his friend, the geologist and future Italian finance minister Quintino Sella in 1864. Shortly before the La Spezia Congress, Capellini was taking part in the 49th session of the SSSN in Geneva, when he was informed by his friend, De Mortillet, that a leading palaeontologist, Edouard Lartet, was considering the possibility of having a congress of specialists on anthropology and prehistorical archaeology in Paris during the International Exhibition planned for 1867. Both Lartet and De Mortillet were convinced that such a proposal would be more easily accepted if it were formally presented by a country other than France (as the authorities would give more credit to a foreign request). Hence they entrusted Capellini with realization of their intent. Capellini accepted because he was already sympathetic to the idea of establishing an International Palaeoethnological Congress. One month later, at the end of the La Spezia Congress (Sept. 21, 1865), Capellini was the first to sign a motion to found an International Palaeoethnological Congress to be convened for the first time in 1866 in Neuchâtel by Desor, and then in 1867 in Paris at the Exposition Universèlle. The motion was approved by acclamation. Only Italian scientists signed the motion; French and Swiss scientists refrained, to get more credit at home and to give the impression of having been asked to organize a large internationally requested congress (Capellini, 1914, v. 2, pp. 143-144). Capellini was proud to have assisted in founding a large international congress during the first convention he had organized and chaired.

\section{The international congresses of Anthropology and pre-Historical Archaeology}

The first session of the new international congress was held in Neuchâtel in 1866 and was successful. The second session was held in Paris 1867 and had 363 registrations, including many non-attending members such as librarians, with $10 \%$ of Italian members and representatives from 28 countries. At the fourth session in Copenhagen in 1869, Capellini, as founder of the Congress, was elected honorary Vice-President, and Bologna was selected as the venue for the next session. Capellini had assured the support of the Italian Government through a telegram from his Bologna friend, Marco Minghetti, the Agriculture and Trade minister and future prime minister.

Thus, Capellini had a superb opportunity to show not only his already renowned diplomatic skills but also his ability to organize a large international congress with over 400 registrations and 300 participants, - even more than there had been in Paris four years before. In reality the Bologna Congress had to be delayed by one year because of the Franco-German war of 1870, which afforded Capellini more time to refine the organization of the congress and to include in the program geological matters such as maps, publications, and field trips in addition to the appropriate anthropological and archaeological ones. A special pre-historic archaeological exhibition was also organized and was opened by H. R. H. Prince Umberto, who had chaired and sponsored the very successful Bologna Congress (Capellini, 1914) (Figure 7). Some months later, with a unanimous vote by the City Council, the honorary citizenship of Bologna was granted to the composer Richard Wagner for artistic reason (Bologna was the first place in Italy to welcome Wagner's operas in 1870) and to the Vice-presidents, President and Secretary General of the congress for scientific reason: Bononiae resonavit fama per Orbem! [the renown of Bologna echoed worldwide] (Capellini, 1914, v. 2, p. 216).

Capellini again played a major role as founder of the congress and as honorary President at the sixth session held in Brussels in 1872. It is important to mention Capellini's advocacy of the maintenance of French as the official and current language of the congress, as agreed in Bologna in 1871.

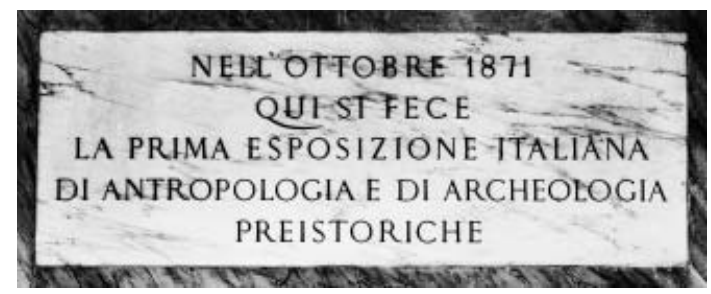

Figure 7 "The first Italian Exhibition of Anthropology and preHistorical Archaeology was held in this place in October 1871" (during the fifth session of the same international congress chaired in Bologna by Capellini). Historical marble inscription in the entrance hall of the Capellini Museum in Bologna. 


\section{Proposal of a Geologic International Congress in Italy (1874)}

On March 3, 1874, Capellini wrote an important reply to a letter from the Italian Minister of Agriculture, Industry, and Trade, H. E. G. Finali, dated February 20, 1874 and concerning the Geological Map of Italy (Capellini, 1877). After recalling his experiences during visits to regions of Europe and North America, Capellini (1877, p, 5) stated [translation with italics and capitals as in the Italian original]:

I believe many travelling geologists would agree with me that the progress of geology is being hampered by nomenclature, often awkward and arbitrarily adopted in different countries, making it difficult to coordinate studies made in different regions; often new names are set up and new discoveries are inferred which have been known for a long time elsewhere, simply because the value of the names and subdivisions adopted by other geologists are not understood. I have no doubt that today's desire of a few is soon going to become the need of many. To respond to such a need, those having the brilliant idea to lead this reform will serve in the most commendable way by making rapid progress in this branch of Natural sciences.

After an expression of total support from the powerful Sella, Capellini (p. 4) then suggested to the Minister:

the opportunity to seek first an agreement among the geologists of different nations about nomenclature and systematic subdivision of the different terrains, and to invite the Directors of the Geological Institute and the most distinguished geologists of the different nations to an International Congress to be held in Rome. In this way the Geological Map of Italy would gain universal approval and act as a standard for large scale geological maps.

With an additional private letter to the Minister, Capellini (p. 7) detailed "the great advantages for both science and Italy of convening the first Geological International Congress using the Geological Map of Italy as a starting point".

In a letter of March 15, 1874, the Minister responded (p. 7):

\begin{abstract}
Although unaware of the geological science, I appreciated the importance for Geology of having a common language, because this is a need of all sciences. Thank you for having privately explained to me Your intent about the geologic Nomenclature to be adopted universally, analogous to what is done in other branches of the natural sciences.

Capellini (p. 9-10) answered again:
\end{abstract}

Accepting and endorsing my proposal would allow Italy to write a beautiful page in the history of the progress of geology ... as done in the past.

\section{Founding Committee of the IGC (1876)}

The formal proposal to inaugurate an IGC, made at the 25th Meeting of the American Association for the Advancement of Science (AAAS) in Buffalo, N. Y., on Friday, August 25, 1876, was published by Mendenhall (1877, p. 355) as follows:

The following resolution from the Standing Committee was adopted.

Resolved, That a Committee of the Association be appointed to consider the propriety of holding an International Congress of Geologists at Paris during the International Exhibition of 1878, for the purpose of getting together comparative collections, maps and sections, and for the settling of many obscure points relating to geological classification and nomenclature, and that to this committee be added our guest Dr. Otto Torell of Sweden and Dr. E. H. von
Baumhauer of the Netherlands, who shall be requested to open negotiations in Europe looking to a full representation of European geologists at the proposed congress; the said Committee to consist of Prof. Wm. B. Rogers, James Hall, J. W. Dawson, J. S. Newberry, T. Sterry Hunt, C. H. Hitchcock, and R. Pumpelly, in behalf of the Association, with the addition of Dr. Otto Torell and Dr. E. H. Baumhauer.

The International Exhibition of Philadelphia (1876) was also mentioned in the Proceedings of the Buffalo Meeting (p. 341) showing that both events occurred in the same year:

the Centennial Exhibition at Philadelphia was also the means of securing the attendance of numerous foreign savants ....

The same resolution was published with minor changes in the American Journal of Science (v. 12, p. 463, 1867; v. 14, pp. 491-493, 1877) (Ellenberger, 1978).

A summary of the IGC origins consistent with Mendenhall's report is found in Capellini (1877), in the Compte Rendus of the Paris 1878 and Bologna 1881 IGCs (1880, p. 2; 1882, p. 3-4 respectively), and in Capellini (1914, p. 251-255). A complete French translation of the Buffalo report was published in the Compte Rendu of the Bologna 1881 IGC (1882, p. 3-4). Comparing the two proceedings with Mendenhall's report it appears that the Paris proceedings lists also Lesley and Huxley under the members of the founding committee whereas the Bologna proceedings add Huxley only. These discrepancies may reflect differences in the English, French, and German versions of the resolution circulated worldwide as compared with the version published by Mendenhall (1877). Almost all Comptes Rendus of IGCs through Madrid 1926 (thus including Washington 1899) report the founding committee being set up in Buffalo 1876 (with a printing error for the Toronto 1913 IGC, which dates the Buffalo Meeting at 1878). Unexpectedly, the Compte Rendu of the Pretoria 1929 IGC (1930, p. xiv), the first written in English, introduced a 'Foundation Committee' with the date 1875 without explanation. This historical mistake was propagated in all subsequent IGC proceedings, including those for Washington 1933 and 1989.

The establishment of the correct date is simply made by checking the dates of the AAAS meetings in Buffalo: Aug. 15, 1866 and Aug. 23, 1876. So 1876 is the true birth date of the IGC founding committee, as stated by Capellini (1877).

As shown above, the founding committee was almost completely composed of friends and/or correspondents of Capellini. As soon as Capellini was directly informed of the resolution from Buffalo and Philadelphia, he immediately reacted, but only to have international recognition of the priority of his idea to convene an IGC for the purposes he had previously espoused. He asked the Minister and Sella to be allowed to publish his earlier correspondence with the Ministry about his suggestion to convene a Geological International Congress in Italy (Capellini, 1877), and, based on this, succeeded in obtaining prompt international assurance that the second IGC should be assigned to Italy, as it was.

It is tempting to speculate that the French geologists, being aware of the ideas of Capellini, tried to repeat the steps taken to found the International Congress of Anthropology and pre-Historical Archaeology (through the motion of Capellini, see above). To get more credit for their intent to organize the first IGC in Paris during the 1878 International Exhibition, they probably asked North American geologists to decide about the foundation of the congress and to invite the French colleagues to organize the first session, as they did.

As a recognition that Capellini had expressed the idea of an IGC long before the North American founding committee, he was elected Vice President of the first IGC held in Paris in 1878, and was invited to organize the second IGC in Italy. The evening before the closing session on Sept. 3, 1878, the secretary of the founding committee, Sterry Hunt, with the future of the Congress in mind, reviewed the history of its origin and, acknowledging the role played by Capellini and Sella, stated that the venue of the 2nd IGC should be Bologna, with Italy contributing to the great international effort of geologists. So the circle about the origin of the IGC was closed, the mystery solved, and all players given their appropriate credit. During the clos- 


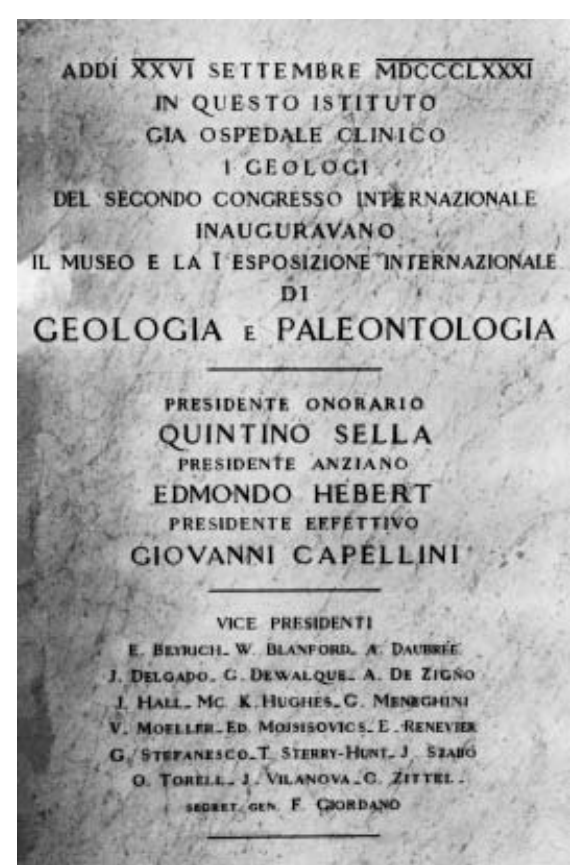

Figure 8 Marble inscription to celebrate the opening of the 2nd IGC Bologna 1881 and the 1st International Exhibition of Geology and Palaeontology. Historical plaque, entrance hall of the Capellini Museum, Bologna.

ing session at the Trocadero in Paris, the resolution of Sterry Hunt passed by acclamation, with Bologna as the venue, Sella as Honorary President, and Capellini as effective President of the 2nd IGC.

The first step made by Capellini was to ask the old friend of his youth, now King Umberto I of Italy, to accept the position of Protector of the Congress. The King granted the Organizing Committee immediate high funding. Umberto was pleased to remember the
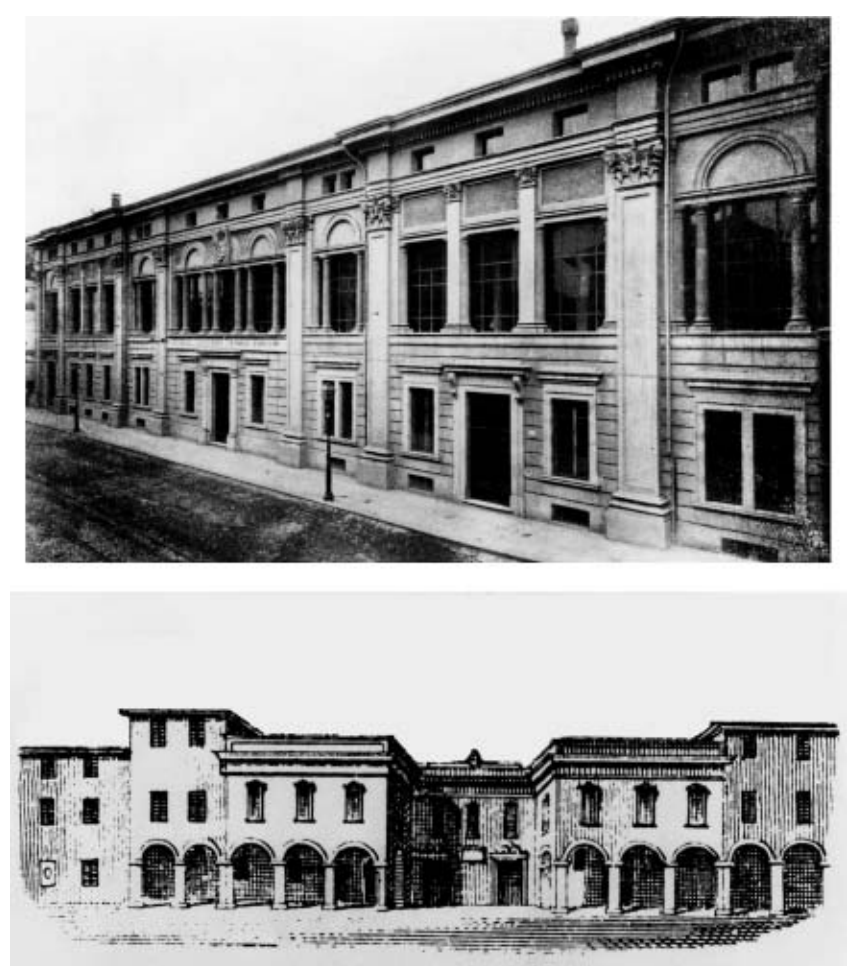

Figure 9 Original front view of the Capellini Museum in Bologna during the 2nd IGC 1881, and its new façade built in 1911 (above). cooperation with Capellini as the leader of the International Congress of Antropology and Pre-Historical Archaeology in Bologna in 1871 and Capellini's intention subsequently to organize a similar International Congress of Geology in Italy.

The second step was to open an international contest, 'Pour l'unification des figurés géologiques', with a very high prize. In this way, Capellini sought to bring reality his old aspiration, which he had discussed with so many colleagues during his North American trip. This is a pointer also to the difference in results and the amount of work done by the first two IGCs. Capellini transformed the IGC from a simple gathering of geologists to discuss common scientific and communication problems into a network of commissions (as an example, the still active IUGS International Commission on Stratigraphy) charged with preparing in advance documentation and proposals on problematic issues to be resolved or agreed at the Congress (Anonymous, 1882 , p. 10-12). This is, however, a different matter from the founding of the Congress, and is one to be addressed separately.

To back up assumption about the reason for the founding committee of the IGC refraining from asking to organize an IGC in North America until thirteen years after the founding resolution was introduced, there is reproduced below the historical marble inscription placed in the entrance hall of the Capellini Museum in Bologna (Figure 8).

It appears that at least four vice-presidents representing the chairman and members of the Buffalo founding committee had agreed to acknowledge Capellini's priority and to support his claim to organize the 2nd IGC in Bologna. This is actually witnessed by Sterry Hunt's address at the closing session of Bologna, October 2, 1881:

$N$ 'est-ce-pas, en effect, notre sympatique président, $M$. Capellini, qui, avant même la formation du Comité fondateur de Philadelphie, avait déjà de son coté proposé la réunion d'un Congrès géologique en Italie, et avait publié sur l'urgence de cette mesure une intéressante correspondance? L'Italie avait donc tous les droits ... (Anonymous, 1882, p. 192). [Is it not, indeed, our congenial president, Mr Capellini, who had himself already suggested to gather a geological Congress in Italy, even before the appointment of the Philadelphia founding Committee, and had published an interesting correspondence on the urgent need of this action? Thus, Italy had all rights ....

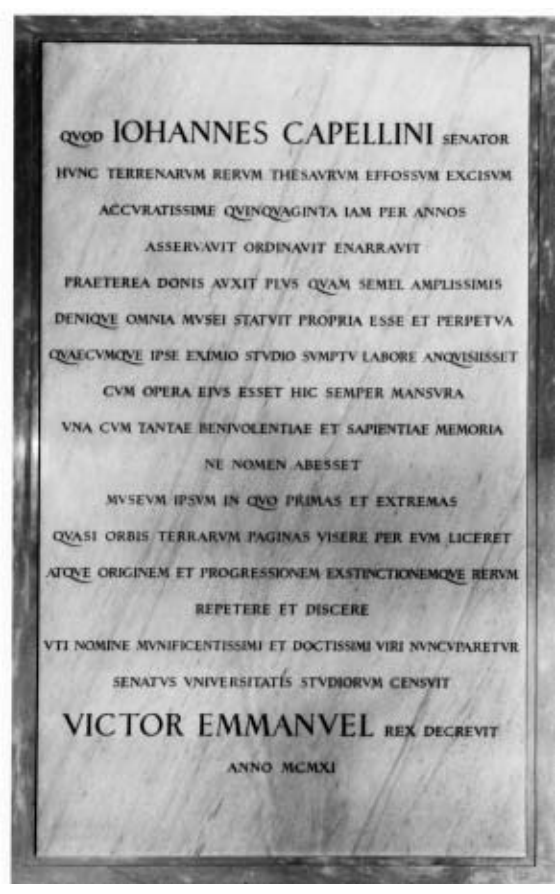

Figure 10 Marble inscription to name the geological museum of Bologna after G. Capellini in 1911. Historical plaque, entrance hall of the Capellini Museum, Bologna. 
So, eventually Capellini succeeded in realizing his last two titanic dreams on the same day, September 26, 1881: to establish a new great geological museum in Europe (Figure 9) at the opening of the 2nd IGC and the 1st International Geological Exhibition in Bologna.

Three decades after, well aware and proud of the learned and munificent man, who was still alive, the Bologna academic senate suggested, and the King of Italy, Vittorio Emanuele III, proclaimed that the Bologna Museum be named after Giovanni Capellini (Figure 10). The rationale is expressed in the marble plaque placed in front of the memorial inscription of the 2nd IGC: "to show almost the first and last pages of the planet Earth and to reproduce and teach the origin, the progress and the extinction of Earth's things".

\section{Acknowledgement}

The critical reviews of an early version of this paper by Charlotte Schreiber, Glen Caldwell, and Ellis Yochelson, and by an anonymous referee are gratefully acknowledged.

\section{References}

Anonymous, 1880, Congrés International de Géologie: Compes Rendus Comité Congrès Conferences, 21, Paris, 1878, Paris, Imprimerie Nationale, $313 \mathrm{pp}$

Anonymous, 1882, Congrès Géologique International: Compte Rendu 2me Session, Bologne, 1881, Bologne, Fava et Garagnani, 663 pp.

Anonymous, 1997, General Proceedings: 30th International Geological Congress, Beijing, China, 1996, 178 pp.

Capellini, G., 1864, Relazione di un viaggio scientifico nell'America Settentrionale: Bologna, Tipi Gamberini e Parmeggiani, 44 pp.

Capellini, G., 1867, Ricordi di un viaggio scientifico nell'America Settentrionale nel 1863: Bologna, Tipografia Giuseppe Vitali, 279 pp.

Capellini, G., 1877, Sulla proposta di un Congresso Internazionale Geologico in Italia: Bologna, Fava e Garagnani, 11 pp.
Capellini, G., 1914, Ricordi: Bologna, Zanichelli, vol. 1, 242 pp.; vol. 2, $356 \mathrm{pp}$.

Ellenberger, F., 1978, The First International Geological Congress, Paris, 1878; Episodes, vol. 1978, no. 2, pp. 20-24.

Hanshaw, B. B., 1990, General Proceedings: 28th International Geological Congress, Washington, D.C. USA, 1989, 185 pp.

Mendenhall, T. C., 1877, Report of General Secretary: Proceedings American Association Advancement of Science, twenty-fifth meeting, Buffalo, N.Y., August 1876, 1876 - vol., 25, pp. 345-360.

Sarjeant, W. A. S., 1980, Geologists and the History of Geology: Macmillan Reference Books, London, Macmillan, 5 volumes, $4526 \mathrm{pp}$.

Vai, G. B., 1995, L'opera e le pubblicazioni geologiche di Scarabelli, in Pacciarelli, M., and Vai, G. B. eds, La Collezione Scarabelli 1 Geologia: Musei Civici di Imola, Bologna, Grafis Edizioni, pp. 49-104.

Professor Gian Battista Vai is teaching Stratigraphic Geology at Department of Earth and GeologicalEnvironmental Sciences, University of Bologna. His research concentrates on Mediterranean Palaeozoic. He was member of the ICS Silurian/ Devonian Boundary Committee, Silurian and Devonian subcommissions, and is currently member of the Neogene and Quaternary subcommissions. He was member and Vice Chairman of the IGCP Board (1980-1986). He served as head of the Italian delegation at the 30th and 31 st IGCs in Beijing and Rio de Janeiro respectively, and is President of the Italian National Committee for IUGS.

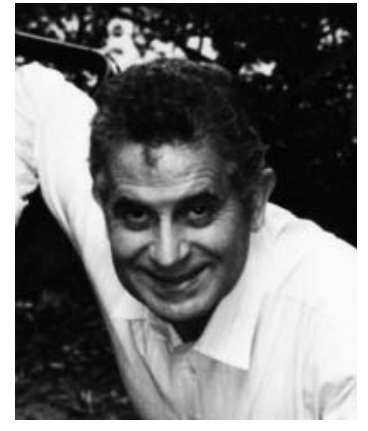

\title{
Hutchison 'Young Scientist' Fund
}

William Watt Hutchison, "Hutch" to his many friends around the world, was a Scots-born Canadian geologist who served Canada and the IUGS in myriad dynamic and creative ways. Most notably, he served as the IUGS Secretary General (1976-1980) at a pivotal time in its history, and as IUGS President (1984-1987). The same boundless energy, enthusiasm, skill in communications, and ability to foster teamwork that characterized his work with the IUGS also carried him to preeminent scientific administrative positions in the Canadian Government, where he served as Director General of the Geological Survey of Canada and as Assistant Deputy Minister of Earth Sciences. His distinguished career was terminated in 1987 by his untimely death at the age of 52, following a painful struggle with cancer.

One of Hutch's last wishes was to establish under IUGS auspices a memorial foundation intended to promote the professional growth of deserving, meritorious young scientists from around the world by supporting their participation in important IUGSsponsored conferences. The first 3 beneficiaries of the Hutchinson "Young Scientist Foundation" attended the 28th International Geological Congress (IGC) in Washington, D.C., in 1989. However, income earned as interest on the Hutchison fund is insufficient to sustain comparable grants every four years without seriously eroding the principal. For that reason, the IUGS made no grants from the fund for the 29th and the 30th IGCs, preferring instead to strengthen the fund by allowing it to earn interest for a longer period of time and by appealing for donations from the international geologic community. And in 2000, 6 awardees received financial support from the Fund to attend the 31st IGC in Rio de Janeiro, Brazil.

The Hutchison "Young Scientist Foundation" is a worthy cause that honors a fine, caring man and a distinguished, publicspirited scientist and administrator. The foundation also celebrates and promotes those things that gave Hutch the most professional satisfaction: geology, international scientific collaboration, and stimulating young minds.

The IUGS welcomes contributions to the Hutchison "Young Scientist Foundation." Please send donations to:

\author{
Dr. John A. Reinemund \\ 945 Oakwood Lane \\ Myrtle Beach, SC 29572 \\ Fax: 843-272-4128 \\ Tel: 843-361-9074
}

Checks in US dollars or Visa/Mastercard (please include account number and expiration date) are preferred in order to avoid the high cost of currency conversions. Residents of the U.S.A. are reminded that charitable gifts of this nature are tax deductible. 